\title{
ANALISIS PENGUKURAN KINERJA DENGAN SISTEM BALANCED SCORECARD PADA RUMAH SAKIT YOS SUDARSO PADANG
}

\author{
Desi Areva \\ Dosen Program Studi Pendidikan Ekonomi STKIP- PGRI Sumbar \\ Jl. Gunung Pangilun No.1, Padang Sumatera Barat \\ Email: desiareva@yahoo.co.id
}

Submitted: 2012.09.17 Reviewed: 2012.09.28 Accepted: 2012.10.18

http://dx.doi.org/10.22202/economica.2012.v1.i1.112

\begin{abstract}
This study describes the use of the Balanced Scorecard as a measure of hospital performance. The formulation of the problem is how the performance of Yos Sudarso Hospital when assessed by a financial perspective. The purpose of this study was to determine the performance of Yos Sudarso Hospital when assessed by a financial perspective. This research was conducted at the Yos Sudarso Hospital Padang in November 2003 to January 2004. Types of data collected is primary data in the form of interviews with the hospitals and secondary data from a general overview of the company, the income statement of 2000 to 2002, the balance sheet of 2000 to 2002 and other documents that support. Techniques of data collection are interview and observation techniques. While the data analysis techniques used in the financial perspective is ROI, ROA, Current Ratio, Quick Ratio, Receivables Turnover, Average Collection Period, Asset Turnover. The results of this study are as follows: Hospital Performance ODOT Padang is the first ROI in 2002 increased 1\% respectively from 2000 and 2001, ROA from 2001 to 2002 did not increase, current ratio in 2002 decreased their respectively (5.60\%) and (16.60\%), Quick Ratio at the end of 2002 compared with the end of 2001 and 2000 also decreased respectively (5.90\%) and (17.90\%), Average collection In 2002 the time period it takes to collect receivables is 10 days results decreased compared to 2001 and 2000 respectively was 3 days and 4 days, Asset turnover in 2002 was 1.67 times also decreased each is equal to (0.16) times and (0.56) times.
\end{abstract}

\begin{abstract}
Abstrak
Studi ini menjelaskan penggunaan Balanced Scorecard sebagai ukuran kinerja rumah sakit. Rumusan masalahnya adalah bagaimana kinerja Rumah Sakit Yos Sudarso ketika dinilai oleh perspektif keuangan. Tujuan dari penelitian ini adalah untuk mengetahui kinerja Rumah Sakit Yos Sudarso ketika dinilai oleh perspektif keuangan. Penelitian ini dilakukan di Rumah Sakit Yos Sudarso Padang pada bulan November 2003 sampai Januari 2004. Jenis data yang dikumpulkan adalah data primer berupa wawancara dengan rumah sakit dan data sekunder dari gambaran umum perusahaan, laporan laba rugi dari tahun 2000 sampai 2002 , neraca tahun 2000 untuk tahun 2002 dan dokumen lain yang mendukung. Teknik pengumpulan data yang wawancara dan observasi teknik. Sedangkan teknik analisis data yang digunakan dalam perspektif keuangan adalah ROI, ROA, Current Ratio, Quick Ratio, Perputaran Piutang, rata Collection Period, Perputaran Aset. Hasil penelitian ini adalah sebagai berikut: Kinerja Rumah Sakit ODOT Padang adalah ROI pertama tahun 2002 meningkat 1\% masing-masing dari tahun 2000 dan 2001, ROA 2001-2002 tidak meningkat, rasio lancar pada tahun 2002 menurun mereka masing-masing (5,60\%) dan ( 16,60\%), Quick Ratio pada akhir tahun 2002 dibandingkan dengan akhir tahun 2001 dan 2000 juga mengalami penurunan masing-masing (5,90\%) dan (17,90\%), rata-rata koleksi tahun 2002 periode waktu yang dibutuhkan untuk mengumpulkan piutang adalah 10 hari hasil menurun dibandingkan untuk tahun 2001 dan 2000 masing-masing adalah 3 hari dan 4 hari, omset Asset pada tahun 2002 adalah 1,67 kali juga mengalami penurunan masing-masing sebesar $(0,16)$ kali dan $(0,56)$ kali.
\end{abstract}

Keywords : Balance Scorecard, ROI, ROA, Current Ratio, Quick Ratio 


\section{PENDAHULUAN}

Setiap perusahaan akan berusaha mengendalikan seluruh aktifitas personelnya dengan sebaik-baiknya, baik itu yang menyangkut aktivitas keuangan maupun non keuangan. Pengendalian ini akan dilaksanakan melalui suatu sistem yang disebut dengan sistem pengendalian manajemen. Dengan adanya sistem pengendalian manajemen ini maka pihak manajemen perusahaan dapat memastikan apakah perusahaan telah melaksanakan visi dan misi serta strategi perusahaan yang telah direncanakan sebelumnya atau tidak. Pelaksanaan visi, misi dan strategi perusahaan pada akhirnya akan bermuara pada pencapaian tujuan dari perusahaan itu sendiri.

Kaplan dan Norton (1992: 248) mensponsori studi tentang pengukuran kinerja dalam organisasi masa depan. Studi ini didorong oleh kesadaran bahwa ukuran kinerja keuangan yang digunakan selama ini untuk mengukur kinerja organisasi tidak lagi memadai. Hasil studi tersebut diterbitkan dalam sebuah artikel berjudul "Balanced Scorecard Measures That Driver Performance" dalam Havard Bussines Review, dan menyimpulkan bahwa untuk mengukur kinerja di dalam organisasi masa depan, diperlukan ukuran komprehensif yang mencakup empat perspektif: keuangan, customer, proses bisnis/intern, serta pembelajaran dan pertumbuhan. Ukuran ini disebut Balanced Scorecard, yang cukup komprehensif untuk memotivasi manajer dalam mewujudkan kinerja dalam ke empat perspektif tersebut, agar keberhasilan keuangan yang diwujudkan perusahaan bersifat sustainable (berjangka panjang).

Balanced scorecard dapat juga diterapkan pada sebuah rumah sakit. Walaupun kegiatan utama rumah sakit itu adalah untuk kepentingan sosial, namun tidak mengabaikan keuntungan untuk menunjang kelancaran kegiatan operasional rumah sakit tersebut. Rumah Sakit Yos Sudarso Padang semenjak tahun 2000 sampai sekarang telah menerapkan sistem Balanced Scorecard.

Berdasarkan rumusan masalah di atas maka perumusan masalah pada penulisan skripsi ini adalah menilai bagaimanakah kinerja Rumah Sakit Yos Sudarso dengan menggunakan sistem balanced scorecard jika dinilai berdasarkan perspektif keuangan?

Penelitian ini bertujuan: untuk mengetahui kinerja Rumah Sakit Yos Sudarso dengan menggunakan sistem balanced scorecard, jika dinilai berdasarkan perspektif keuangan.

\section{a. Pengukuran Kinerja}

Mulyadi (1993:419) mendefinisikan penilaian kinerja sebagai berikut: "Penentuan secara periodik efektifitas operasional suatu organisasi dan karyawannya berdasarkan sasaran standar dan kriteria yang telah ditetapkan sebelumnya". Pengertian ini dilandasi oleh keyakinan bahwa organisasi pada dasarnya dijalankan oleh manusia, maka penilaian kinerja sesungguhnya merupakan penilaian atas perilaku manusia dalam melaksanakan peran yang mereka lakukan dalam perusahaan.

Dalam Standar Akuntansi Keuangan (SAK) yang disusun Ikatan Akuntansi Indonesia (IAI) (1995:7) juga dijelaskan tentang pentingnya informasi kinerja perusahaan, yaitu:

"Informasi kinerja perusahaan, terutama profitabilitas, diperlukan untuk menilai perubahan potensial sumber daya ekonomi yang mungkin dikendalikan di masa depan. Informasi fluktasi kinerja adalah penting dalam hubungan ini. Informasi kinerja bermanfaat untuk memprediksi kapasitas perusahaan dalam menghasilkan arus kas dan sumber daya yang ada. Di samping itu, informasi tersebut juga berguna dalam memanfaatkan tambahan sumber daya".

Dari pengertian ini dapat dilihat bahwa informasi dari penilaian kinerja ini dibutuhkan tidak hanya untuk kepentingan perusahaan dalam jangka pendek saja. Tetapi juga berperan penting dalam proyeksi kepentingan perusahaan dalam jangka panjang. Pengukuran kinerja menurut Anthony dan Dearden (1992:156) merupakan kunci pengawasan dan pengendalian manajemen yang efektif atas sumber daya yang ada dalam organisasi, karenanya pengukuran kinerja menempati posisi yang strategis dan selalu mendapat perhatian khusus dari manajemen perusahaan. Hal ini 
wajar karena melalui pengukuran kinerja, manajemen perusahaan dapat mengetahui efektifitas dalam efisiensi seluruh aktivitas perusahaan dalam mencapai tujuannya

\section{Konsep Balanced Scorecard}

Menurut Mulyadi dan Setiawan (2001:334) balanced scorecard adalah sekumpulan ukuran kinerja yang mencakup empat perspektif keuangan, customer, proses bisnis/intern, dan pembelajaran dan pertumbuhan. Kata "balanced" dalam balanced scoreclard berarti bahwa dalam pengukuran kinerja harus terdapat keseimbangan antara ukuran keuangan dan ukuran non keuangan (ukuran operasional). Manajer dituntut untuk menghasilkan kinerja keuangan yang diakibatkan dari kinerja operasional.

Sedangkan menurut Kaplan dan Norton (1992:71) balanced scorecard meliputi ukuran-ukuran keuangan dan non keuangan yang terdiri dari kepuasan konsumen, proses internal bisnis, serta aktivitas-aktivitas inovasi dan pengembangan, yang mana ukuran non keuangan ini merupakan driver dari kinerja keuangan di masa depan. Balanced scorecard memungkinkan manajer memperhatikan bisnis dari empat perspektif: perspektif keuangan, perspektif customer, perspektif proses bisnis/intern dan perspektif pembelajaran dan pertumbuhan.

Supriyono (2000:143) mendefinisikan balanced scorecard sebagai, "Salah satu alat pengukuran kinerja yang menekankan pada keseimbangan antara ukuran-ukuran strategis yang berlainan satu sama lain dalam usaha untuk mencapai keselarasan tujuan sehingga mendorong karyawan bertindak demi kepentingan perusahaan."

\section{Pengukuran Kinerja dengan Rerangka Balanced Scorecard}

a. Sistem Manajemen Kinerja Terpadu dengan Rerangka Balanced Scorecard

Menurut Mulyadi, (2001:145) sistem manajemen kinerja terpadu adalah sistem manajemen strategik yang difokuskan untuk meningkatkan kinerja personel dalam melipatgandakan kinerja keuangan perusahaan berjangka panjang. Sistem manajemen kinerja di desain untuk memungkinkan perusahaan melaksanakan rapid quantum-leap improvement secara bersistem. Untuk lebih memfokuskan rapid quantum-leap improvement ke usaha untuk melipatgandakan kinerja keuangan berjangka panjang, perusahaan perlu secara khusus mendesain sistem manajemen kinerja terpadu. Sistem manajemen kinerja terdiri dari dua komponen utama:

a. Sistem perencanaan kinerja

1). Perumusan strategi

2). Perencanaan strategi

3). Penyusunan program

4). Penyusunan anggaran

b. Sistem pengelolaan kinerja

Disini kinerja personel dinilai, dianalisis, diumpanbalikkan kepada personel dan diberi penghargaan. Agar pelaksanaan sistem manajemen kinerja dapat dilaksanakan dengan baik, maka suatu perusahaan harus memiliki suatu sistem manajemen yang komprehensif, koheren dan terukur dan sistem seperti ini disebut juga dengan "Sistem Manajemen Kinerja".

Dari gambar tersebut dapat diuraikan bahwa, kinerja direncanakan dan diwujudkan secara bersistem melalui sistem manajemen strategik yang difokuskan untuk melipatgandakan kinerja keuangan perusahaan. Kinerja direncanakan melalui sistem perencanaan kinerja yang terdiri dari empat tahap: perumusan strategi, perencanaan strategi, penyusunan program, dan penyusunan anggaran. Kinerja yang direncanakan kemudian diwujudkan melalui sistem pengelolaan kinerja yang terdiri dari dua tahap yaitu implementasi dan pemantauan.

\section{Balanced Scorecard merupakan} sistem pengukuran kinerja yang cocok digunakan dalam manajemen kontemporer, yang memanfaatkan secara ekstensif dan intensif teknologi informasi dalam bisnis. Ukuran kinerja diarahkan untuk memotivasi personel dalam mewujudkan visi dan sasaran yang strategik perusahaan. Pendekatan Balanced Scorecard menetapkan sasaran dan strategi yang sulit untuk diukur. Namun, berbagai sasaran strategik dari kelompok non keuangan mampu menjelaskan penyebab 
keberhasilan atau kegagalan pencapaian sasaran strategik dari persektif keuangan.

\section{b. Ukuran Pengendalian Kinerja dengan Rerangka Balanced Scorecard}

1) Perspektif keuangan

Menurut Mulyadi dan Setiawan (2001:348) pengukuran kinerja keuangan mengidentifikasi apakah implementasi strategi perusahaan memberikan kontribusi terhadap peningkatan botton line. Tujuan perspektif pemegang saham yaitu untuk mempertahankan kehidupan, memperoleh keberhasilan dan kesejahteraan perusahaan.

Ukuran kinerja keuangan yang sering digunakan terbagi menjadi 3 bagian besar, yaitu:

a) Rasio profitabilitas, yang mengukur efektifitas manajemen berdasarkan hasil pengembalian yang dihasilkan dari penjualan dan investasi.

b) Rasio pertumbuhan, yang mengukur kemampuan perusahaan untuk mempertahankan posisi ekonomisnya dalam pertumbuhan perekonomian dan dalam industri atau pasar produk tempatnya beroperasi.

c) Ukuran penilaian, mengukur kemampuan manajemen untuk mencapai nilai-nilai pasar yang melebihi pengeluaran kas.

Ukuran kinerja keuangan menunjukkan apakah strategi, sasaran strategik, inisiatif strategik dan impelementasinya mampu memberikan kontribusi dalam menghasilkan laba bagi perusahaan. Ukuran keuangan umumnya diwujudkan dalam profitabilitas, pertumbuhan dan shareholder value.

2) Perspektif customer

Menurut Mulyadi dan Setiawan (2001:342) untuk mewujudkan visi customers yang puas, customers harus merupakan fokus strategi, organisasi harus berangkat dari jawaban atas pertanyaan berikut:

a) Kebutuhan customers apa yang kita penuhi?

b) Siapakah customers kita? c) Dalam bisnis apa kita memuasi kebutuhan customers?

Menurut Mulyadi dan Setiawan (2001:344) customers dalam lingkungan bisnis memegang kendali, manajemen puncak berkepentingan untuk mengukur kinerja perusahaan dari perspektfi customers. Balanced scorecard menuntut manajer untuk menterjemahkan visi organisasi ke dalam sasaran-sasaran strategik yang benar-benar ditujukan untuk memuaskan kebutuhan customers.

3) Perspektif proses bisnis/intern

Menurut Mulyadi dan Setiawan (2001:345-346) setelah dirumuskan sasaran strategik dari perspektif customers, pertanyaan berikutnya yang perlu di jawab: Apa yang terbaik kita lakukan untuk memuasi kebutuhan customers kita? Untuk menjawab pertanyaan itu, dirumuskan sasaran strategik untuk pembangunan tiga macam proses bisnis/intern berikut ini: a) proses inovasi, b) proses operasi, c) proses layanan pasca penjualan. Proses bisnis/intern merupakan rangkaian aktivitas yang digunakan oleh organisasi untuk menghasilkan produk dan jasa bagi customers.

4) Perspektif pembelajaran dan pertumbuhan

Menurut Mulyadi dan Setiawan (2001:346-347) untuk mengoperasikan proses bisnis/intern dalam rangka menghasilkan produk dan jasa yang memiliki value bagi customers, organisasi memerlukan personel yang produktif dan berkomitmen. Produktifitas personel ditentukan oleh kompetensi personel dan ketersediaan prasarana yang dibutuhkan untuk menjalankan proses bisnis/intern. Komitmen personel ditentukan oleh kualitas lingkungan kerja yang dibangun dalam organisasi.

Oleh karena kebutuhan customers senantiasa mengalami perubahan karena terjadinya persaingan yang semakin tajam, organisasi perlu melakukan improvement secara berkelanjutan terhadap proses bisnis/intern yang digunakan untuk menghasilkan value bagi customers. Untuk memungkinkan terlaksananya improvement 
terhadap proses bisnis/intern, organisasi menuntut seluruh personelnya untuk memiliki kemampuan belajar secara berkelanjutan. Kemampuan organisasi untuk senantiasa melakukan inovasi produk dan jasa baru, improvement terhadap proses bisnis/intern, dan belajar menyebabkan organisasi mampu memasuki pasar baru, meningkatkan pendapatan dan laba, atau secara singkat, organisasi mampu bertumbuh dan oleh karena itu mampu meningkatkan nilai bagi pemegang saham (shareholders).

\section{METODE PENELITIAN Jenis Penelitian}

Jenis penelitian yang dilakukan adalah penelitian yang bersifat deskriptif. Menurut Nazir (1999: 63) metode penelitian deskriptif adalah suatu metode yang dipakai dalam meneliti status kelompok manusia, suatu objek, suatu kondisi, suatu sistem pemikiran maupun suatu kelas peristiwa pada masa sekarang. Penelitian ini akan menggambarkan, menjelaskan, menginterprestasikan suatu kejadikan, peristiwa, atau fenomena yang terjadi pada suatu objek. Menurut Irawan (1999: 60) penelitian deskriptif adalah penelitian yang bertujuan mendeskripsikan atau menjelaskan sesuatu hal seperti apa adanya.

\section{Tempat Penelitian}

Penelitian ini dilakukan di Rumah Sakit Yos Sudarso Padang. Waktu penelitian akan dilaksanakan selama lebih kurang tiga bulan, yang dimulai dari bulan November 2003 sampai bulan Januari 2004.

\section{Jenis Data}

Adapun jenis data yang diperlukan dan dipergunakan dalam penelitian ini adalah:

1. Data primer

Data primer adalah data yang diperoleh dari Rumah Sakit Yos Sudarso melalui

1. Mengukur kinerja dari perspektif keuangan
a. $\quad$ ROI $=\frac{\text { Penjualan }}{\text { Operating assets }} \times \frac{\text { Laba Usaha }}{\text { Penjualan }}$$$
=\frac{\text { Laba Usaha }}{\text { Operating Usaha }} \times 100 \%
$$
b. $\mathrm{ROA}=\frac{\text { Laba Operasi }}{\text { TotalAktiva }} \times 100 \%$
c. Ratio Likwiditas :

tanya jawab dan wawancara langsung dengan pejabat yang berwenang.

2. Data Sekunder

Data sekunder adalah mengumpulkan data-data, catatan dan dokumen-dokumen lainnya yang berhubungan dengan sistem balanced scorecard. Diantaranya: gambaran umum Rumah Sakit Yos Sudarso, laporan Rugi Laba tahun 2000 s/d 2002, Neraca tahun 2000 s/d 2002, dan data-data lainnya yang mendukung data primer.

\section{Teknik Pengumpulan Data}

Dalam melaksanakan penelitian ini data-data yang diperlukan peneliti diperoleh dari:

Observasi

Pengamatan langsung pada perusahaan dengan membuat catatan sistematis mengenai hal-hal yang diperlukan sehingga diperoleh data yang nyata dan objektif.

Wawancara

Penulis mengadakan wawancara secara lansung dengan pihak-pihak yang bersangkutan untuk memperoleh data-data dan informasi yang diperlukan.

\section{Studi Dokumenter}

Penulis melakukan studi dokumenter dengan cara mengumpulkan data-data tertulis, dokumen-dokumen, laporan yang berhubungan dengan permasalahan penelitian.

\section{Teknik Analisa Data}

Adapun teknik yang digunakan untuk mengukur kinerja Rumah Sakit Yos Sudarso dengan menggunakan sistem Balanced Scorecard berdasarkan perspektif keuangan. 
1) Current Ratio $=\frac{\text { Aktiva Lancar }}{\text { Hu tan g Lancar }}$

2) Quick Ratio $=\frac{\text { Aktiva Lancar }- \text { Persediaan }}{\text { Hu tan g Lancar }}$

3) Perputaran piutang $=\frac{\text { Penjualan }}{\text { Rata }- \text { rata Piu tan } g}$

4) Average Collection Period $=\frac{360}{\text { Perputaran Piu tang }}$

d. Ratio Rentabilitas

1) Asset turn over $=\frac{\text { Penjualan bersih }}{\text { Aktiva usaha }}$

\section{Definisi Operasional}

Untuk menghindari penafsiran yang berbeda terhadap penulisan skripsi ini, maka perlu dijelaskan istilah atau pengertian dari variabel yang terdapat dalam penelitian ini adalah sebagai berikut:

Pengukuran kinerja ialah penilaian yang dilakukan dan ditujukan untuk menilai kinerja Rumah Sakit Yos Sudarso dengan membandingkan antara target yang telah ditetapkan sebelumnya dengan realisasi yang telah terjadi dan dapat berupa persentase.

Balanced scorecard ialah alat ukur komprehensif yang digunakan untuk menilai kinerja seseorang atau devisi/bagian yang ada di dalam RS. Yos
Sudarso berdasarkan aspek keuangan dan aspek non keuangan

Perspektif keuangan ialah penilaian yang ditujukan kepada Rumah Sakit Yos Sudarso dengan melihat pertumbuhan ROI, ROA, Current Ratio, Quick Ratio, Perputaran piutang, Average Collection Period, Asset Turnover.

\section{PEMBAHASAN}

Pengukuran Kinerja dengan Sistem Balanced Scorecard Ditinjau dari Perspektif Keuangan

ROI

Tabel 1. Uraian ROI

\begin{tabular}{|c|c|c|c|}
\hline Keterangan & 2002 & 2001 & 2000 \\
\hline a. Laba sebelum pajak & $349.850 .136,55$ & $259.652 .321,25$ & $201.245 .369,52$ \\
\hline c. Jumlah aktiva usaha & $\begin{array}{r}9.938 .381 .490,7 \\
0\end{array}$ & $\begin{array}{r}8.019 .028 .368,0 \\
3\end{array}$ & 6.191.580.177,91 \\
\hline Return on investment (a:c) & $4 \%$ & $3 \%$ & $3 \%$ \\
\hline
\end{tabular}

$$
\begin{aligned}
\text { ROI Tahun } 2000 & =\frac{\text { Laba Sebelum Pajak }}{\text { Total Aktiva }} \times 100 \% \\
& =\frac{201.245 .369,52}{6.191 .580 .177,91} \times 100 \% \\
& =3 \% \\
\text { ROI Tahun } 2001 & =\frac{259.652 .321,25}{8.019 .028 .368,03} \times 100 \% \\
& =3 \%
\end{aligned}
$$




$$
\text { ROI Tahun } \begin{aligned}
2002 & =\frac{349.850 .136,55}{9.938 .381 .490,70} \times 100 \% \\
& =4 \%
\end{aligned}
$$

Dari Tabel 2 di atas dapat dilihat bahwa Return On Investment tahun 2002 mengalami kenaikan dari tahun 2001 sebesar $1 \%$. Sedangkan dari tahun 2000 ke 2001 tidak mengalami perubahan. Peningkatan ROI dari tahun ke tahun yang terlihat pada Tabel 2 di atas di pacu oleh 2 (dua) penyebab yaitu: peningkatan pertumbuhan pendapatan dan penurunan biaya. Dari Tabel 2 di atas \% pertumbuhan pendapatan dari tahun ke tahun selalu meningkat, dari tahun 2000 ke tahun ROA
$200130 \%$ dan dari tahun 2001 ke tahun 2002 meningkat menjadi $13 \%$. Untuk biaya dari tahun ke tahun selalu meningkat hal ini disebabkan dari kenaikan gaji perawat, honor dokter jaga, penambahan barang-barang elektronik serta biaya perawatannya dan kenaikan harga bahan baku (obat-obatan) Rumah Sakit.

\begin{tabular}{|c|c|c|c|}
\hline Keterangan & 2002 & 2001 & 2000 \\
\hline a. Laba setelah pajak & 262.387.602,41 & $220.704 .473,06$ & 173.071.017,79 \\
\hline c. Jumlah aktiva usaha & 9.938.381.490,70 & 8.019.028.368,03 & 6.191.580.177,91 \\
\hline Return on Asset (a:c) & $4 \%$ & $3 \%$ & $3 \%$ \\
\hline \multicolumn{4}{|c|}{ ROA $=\frac{\text { Laba Operasi }}{\text { Total Aktiva }} \times 100 \%$} \\
\hline \multicolumn{4}{|c|}{ ROA Tahun $2000=\frac{173.071 .017,79}{6.191 .580 .177,91} \times 100 \%$} \\
\hline \multicolumn{4}{|c|}{$=3 \%$} \\
\hline \multicolumn{4}{|c|}{ ROA Tahun $2001=\frac{220.704 .473,06}{8.019 .028 .368,03} \times 100 \%$} \\
\hline \multicolumn{4}{|c|}{$=3 \%$} \\
\hline \multicolumn{4}{|c|}{ ROA Tahun $2002=\frac{262.387 .602,41}{9.938 .381 .490,70} \times 100 \%$} \\
\hline & $=3 \%$ & & \\
\hline
\end{tabular}

Tabel 2. Uraian ROA

Dari Tabel 3 di atas Return On Asset dari tahun 2000 sampai tahun 2002 tidak mengalami peningkatan maupun penurunan. Return On Asset adalah perbandingan antara laba bersih setelah pajak terhadap total aktiva.

\section{Ratio Likuiditas}

a) Current Ratio
Suatu trend angka ratio yang cenderung tetap memberikan gambaran bahwa Rumah Sakit Yos Sudarso kurang mampu untuk lebih efisien lagi dalam menggunakan total aktivanya.

\begin{tabular}{|c|c|c|c|}
\hline Keterangan & 2002 & 2001 & 2000 \\
\hline
\end{tabular}

\section{Tabel 3. Uraian Likuiditas}




\begin{tabular}{lrrr}
\hline & $($ Rp) & \multicolumn{1}{c}{$(\mathbf{R p})$} & \multicolumn{1}{c}{$(\mathbf{R p})$} \\
\hline $\begin{array}{l}\text { a. Jumlah Aktiva } \\
\text { lancar }\end{array}$ & $\mathbf{5 . 2 5 2 . 1 1 3 . 7 3 0 , 5 4}$ & $\mathbf{4 . 1 6 2 . 7 9 8 . 3 0 3 , 8 0}$ & $\mathbf{3 . 6 1 4 . 7 0 6 . 4 4 5 , 5 1}$ \\
\begin{tabular}{l} 
b. Hutang lancar \\
\multicolumn{2}{c}{ Current Ratio (a:c) }
\end{tabular} & $\mathbf{8 1 7 . 5 9 0 . 0 2 2 , 6 0}$ & $\mathbf{5 9 6 . 8 0 0 . 4 0 7 , 3 5}$ & $\mathbf{4 4 7 . 2 3 4 . 1 4 2 , 5 9}$ \\
\hline
\end{tabular}

1) Current Ratio Tahun $2000=\frac{\text { Jumlah Aktiva Lancar }}{\text { Hu tan g Lancar }} \times 100 \%$

$$
\begin{aligned}
& =\frac{3 \cdot 614 \cdot 706 \cdot 445,51}{447 \cdot 234 \cdot 142,59} \times 100 \% \\
& =80,80 \%
\end{aligned}
$$

2) Current Ratio Tahun $2001=\frac{4.162 .798 .303,80}{596.800 .407,35} \times 100 \%$

$$
=69,80 \%
$$

3) Current Ratio Tahun $2002=\frac{5 \cdot 252.113 .730,54}{817.590 .022,60} \times 100 \%$

$$
=64,20 \%
$$

Dari Tabel 4 di atas dapat dilihat bahwa Current ratio pada akhir tahun 2002 bila dibandingkan dengan akhir tahun 2001 dan 2002 mengalami penurunan, masing-masing adalah sebesar $(5,60 \%)$ dan $(16,60 \%)$. Hal ini disebabkan tingginya kenaikan hutang lancar. Current ratio yang membandingkan antara

Tabel 4. Uraian Likuiditas jumlah aktiva lancar dengan hutang lancar pada saat jatuh tempo. Pada tahun 2002 current ratio Rumah Sakit Yos Sudarso sebesar 64,20\% atau 0,6420 : 1. Artinya

\begin{tabular}{|c|c|c|c|}
\hline Keterangan & $\begin{array}{l}2002 \\
\text { (Rp) }\end{array}$ & $\begin{array}{l}2001 \\
(\mathbf{R p})\end{array}$ & $\begin{array}{l}2000 \\
(\mathbf{R p})\end{array}$ \\
\hline a. Jumlah Aktiva & 5.252.113.730,54 & 4.162.798.303,80 & $3.614 .706 .445,51$ \\
\hline lancar & 695.915.201,03 & 487.547.256,15 & $325.125 .475,55$ \\
\hline $\begin{array}{l}\text { b. Persediaan } \\
\text { c. Hutang lancar }\end{array}$ & $817.590 .022,60$ & $596.800 .407,35$ & 447.234.142,59 \\
\hline Quick ratio $\{(\mathrm{a}-\mathrm{b}): \mathrm{c}\}$ & $55,70 \%$ & $61,60 \%$ & $73,60 \%$ \\
\hline
\end{tabular}
setiap Rp. 1 hutang lancar di jamin dengan Rp. 0,6420 aktiva lancar.

b) Quick Ratio

1) Quick Ratio Tahun $2000=\frac{\text { Jumlah Aktiva Lancar }- \text { Persediaan }}{\text { Hu tan } g \text { Lancar }} \times 100 \%$

$$
\begin{gathered}
=\frac{3.614 \cdot 706 \cdot 445,51-325 \cdot 125 \cdot 475,55}{447.234 \cdot 142,59} \times 100 \% \\
=73,60 \%
\end{gathered}
$$

2) Quick Ratio Tahun $2001=\frac{4.162 .798 .303,80-487.547 .256,15}{596.800 .407,35} \times 100 \%$

$$
=61,60 \%
$$


3) Quick Ratio Tahun $2002=\frac{5.252 .113 .730,54-695.915 .201,03}{817.590 \cdot 022,60} \times 100 \%$

$$
=55,70 \%
$$

Dari Tabel 5 di atas dapat dilihat bahwa Quick ratio pada akhir tahun 2002 dibandingkan dengan akhir tahun 2001 dan 2000, juga mengalami penurunan masingmasingnya sebesar $(5,90 \%)$ dan $(17,90)$. Quick ratio bertujuan untuk mengukur kemampuan Rumah Sakit Yos Sudarso dalam memenuhi kewajiban-kewajibannya dengan

Tabel 6. Uraian Perputaran Piutang tidak memperhitungkan aktiva lancar yang memerlukan waktu yang relatif lama untuk direalisasikan menjadi kas seperti persediaan. Untuk tahun 2002 Quick ratio Rumah Sakit Yos Sudarso adalah 55,70\% atau 0,5570 : 1 . Artinya Rp. 1 hutang lancar dijamin dengan Rp. 0,5570 aktiva lancar.

c) Perputaran Piutang

\begin{tabular}{|c|c|c|c|}
\hline Keterangan & $\begin{array}{l}2002 \\
\text { (Rp) }\end{array}$ & $\begin{array}{l}2001 \\
\text { (Rp) }\end{array}$ & $\begin{array}{l}2000 \\
\text { (Rp) }\end{array}$ \\
\hline a. Penjualan & 16.604 .827 .300 & $14.658 .263 .456,0$ & $13.785 .723 .012,0$ \\
\hline \multirow[t]{2}{*}{ b. Rata-rata Piutang } & ,00 & $\mathbf{0}$ & 0 \\
\hline & 266.833.457,73 & 440.701.359,79 & $216.254 .363,21$ \\
\hline Perputaran Piutang & 63,75 & 54,93 & 37,68 \\
\hline
\end{tabular}

1) Perputaran Piutang Tahun $2000=\frac{\text { Penjualan }}{\text { Rata }- \text { rata Piu tan } g}$

$$
\begin{aligned}
\text { Perputaran piutang } & =\frac{13 \cdot 785 \cdot 723 \cdot 012,00}{216 \cdot 254 \cdot 363,21} \\
& =63,75 \mathrm{x}
\end{aligned}
$$

2) Perputaran piutang Thn $2001=\frac{14.658 \cdot 263.456,00}{440.701 .359,79}$

$$
=54,93 \mathrm{x}
$$

3) Perputaran piutang Thn $2002=\frac{16.604 .827 .300,00}{266.833 .457,73}$

$$
=37,68 \mathrm{x}
$$

Dari Tabel 6 di atas dapat dilihat bahwa perputaran piutang dari tahun ke tahun selalu mengalami penurunan. Perputaran piutang dari tahun 2000 ke tahun 2001 mengalami penurunan sebanyak 8,82 kali, sedangkan dari tahun 2001 ke tahun 2002 mengalami penurunan sebanyak 17,25 kali. Kalau ratio

d) Average Collection Period semakin rendah berarti ada over investment dalam piutang sehingga memerlukan analisa lebih lanjut, mungkin karena bagian kredit dan penagihan bekerja tidak efektif atau mungkin ada perubahan dalam kebijaksanaan pemberian kredit.

\section{Tabel 6. Uraian Average Collection Period}




\begin{tabular}{|c|c|c|c|}
\hline Keterangan & $\begin{array}{l}2002 \\
\text { (Rp) }\end{array}$ & $\begin{array}{l}2001 \\
\text { (Rp) }\end{array}$ & $\begin{array}{l}2000 \\
\text { (Rp) }\end{array}$ \\
\hline a. 360 & 360 & 360 & 360 \\
\hline b. Perputaran piutang & 63,75 & 54,93 & 37,68 \\
\hline Average Collection Period & 5,65 & 6,55 & $\mathbf{9 , 5 5}$ \\
\hline
\end{tabular}

1) Average Collection Period Tahun $2000=\frac{360}{63,75}$

$$
=5,65 \text { atau } 6 \text { hari }
$$

2) Average Collection Period Tahun $2001=\frac{360}{54,93}$

$$
=6,55 \text { atau } 7 \text { hari }
$$

3) Average Collection Period Tahun $2002=\frac{360}{37,68}$

$$
=9,55 \text { atau } 10 \text { hari }
$$

Dari Tabel 7 dapat dilihat bahwa Average collection period, tahun 2002 waktu yang diperlukan untuk mengumpulkan piutangnya adalah 10 hari. Hasil ini mengalami

\section{Ratio Rentabilitas}

a) Asset Turn Over penurunan di bandingkan dengan tahun 2001 dan 2000 masing-masingnya adalah 3 hari dan 4 hari.

Tabel 7. Uraian Asset turn over

\begin{tabular}{lrrr}
\hline \multicolumn{1}{c}{ Keterangan } & \multicolumn{1}{c}{2002} & \multicolumn{1}{c}{2001} & \multicolumn{1}{c}{2000} \\
\hline a. Penjualan bersih & $16.604 .827 .300,00$ & $14.658 .263 .456,00$ & 13.785 .723 .012 .00 \\
b. Jumlah aktiva & $9.938 .381 .490,70$ & $\mathbf{8 . 0 1 9 . 0 2 8 . 3 6 8 , 0 3}$ & $\mathbf{6 . 1 9 1 . 5 8 0 . 1 7 7 , 9 1}$ \\
usaha & & & $3 \%$ \\
\hline \multicolumn{1}{c}{ Asset turn over } & $4 \%$ & $3 \%$ & $3 \%$ \\
\hline
\end{tabular}

1) Asset turn over Tahun $2000=\frac{13.785 .723 .012,00}{6.191 .580 .177,91}$

$$
=2,23 \mathrm{x}
$$

2) Asset turn over Tahun $2001=\frac{14.658 .263 .456,00}{8.019 .028 .368,03}$

$$
=1,83 \mathrm{x}
$$

3) Asset turn over Tahun $2002=\frac{16.604 .827 .300,00}{9.938 .381 .490,70}$

$$
=1,67 \mathrm{x}
$$


Dari Tabel 8 dapat dilihat bahwa Asset Turnover tahun 2002 adalah 1,67 kali. Dimana untuk Rp. 1 aktiva yang digunakan bisa menghasilkan Rp. 1,67 pendapatan. Hasil ini bila dibandingkan dengan tahun 2001 dan 2000 mengalami penurunan masingmasingnya adalah sebesar 0,16 kali dan 0,56 kali.

\section{PEMBAHASAN}

Berdasarkan temuan di atas maka penulis mencoba untuk mengukur kinerja Rumah Sakit Yos Sudarso dengan menggunakan system balanced scorecard berdasarkan perspektif keuangan. Data yang telah penulis peroleh yaitu laporan neraca tahun $2000 \mathrm{~s} / \mathrm{d}$ 2002 dan laporan rugi laba tahun 2000 s/d 2002, data tersebut dapat di lihat pada lampiran 1 dan 2 .

Mengukur kinerja dengan menggunakan system balanced scorecard tolok ukur-tolok ukur yang penulis gunakan berdasarkan tehnik analisa data pada bab 3 yaitu: Return On Investment tahun 2002 mengalami kenaikan dari tahun 2001 dan 2000 masingmasing $1 \%$. Sedangkan dari tahun 2000 ke 2001 tidak mengalami perubahan baik itu peningkatan maupun penurunan. Besarnya ROI akan berubah kalau ada perubahan profit margin atau assets turnover, baik masingmasing atau kedua-duanya. Usaha mempertinggi ROI dengan memperbesar profit margin adalah bersangkutan dengan usaha untuk mempertinggi efisiensi di sektor produksi, pendapatan dan administrasi. Usaha mempertinggi ROI dengan memperbesar assets turnover adalah kebijaksanaan investasi dana dalam berbagai aktiva, baik aktiva lancar maupun aktiva tetap.

Return On Asset dari tahun 2000 sampai tahun 2002 tidak mengalami peningkatan maupun penurunan. Return On Asset adalah perbandingan antara laba bersih setelah pajak terhadap total aktiva. Suatu trend angka ratio yang cenderung tetap, memberikan gambaran bahwa Rumah Sakit Yos Sudarso kurang mampu untuk lebih efisien lagi dalam menggunakan total aktivanya.

Pada tahun 2002 current ratio Rumah Sakit Yos Sudarso sebesar 64,20\% atau 0,6420 : 1. Artinya setiap Rp.1 hutang lancar di jamin dengan Rp. 0,6420 aktiva lancar.
Hasil ini sangat rendah bila dibandingkan dengan standar current ratio yang sebaiknya dimiliki oleh suatu perusahaan menurut Munawir, S (1995:73) yaitu 200\% atau 2: 1. Apabila hasil Current ratio tidak mencapai standar ini maka dapat dikatakan perusahaan mengalami kesulitan untuk membayar hutang lancar pada saat jatuh tempo. Jadi bila hasil Current ratio Rumah Sakit Yos Sudarso dinilai berdasarkan pendapat Munawir adalah sangat rendah karena jumlah aktiva lancar tidak mampu menutupi jumlah hutang lancar.

Untuk tahun 2002 Quick ratio Rumah Sakit Yos Sudarso adalah 55,70\% atau 0,5570 : 1. Artinya Rp. 1 hutang lancar dijamin dengan Rp. 0,5570 aktiva lancar. Berdasarkan pendapat Munawir (1995:74) ratio ini lebih tajam dari current ratio, karena hanya membandingkan aktiva yang sangat likuid (mudah dicairkan atau diuangkan) dengan hutang lancar. Jika current ratio lebih tinggi dari Quick ratio hal ini mengindikasikan kalau investasi perusahaan dalam persediaan sangat tinggi. Dari hal ini dapat disimpulkan bahwa Rumah Sakit Yos Sudarso melakukan investasi yang sangat besar karena Quick ratio Rumah Sakit Yos Sudarso tahun 2000 lebih rendah dari current ratio tahun 2000.

Pada tahun 2002 waktu yang diperlukan Rumah Sakit Yos Sudarso untuk mengumpulkan piutangnya adalah 10 hari. Hasil ini mengalami penurunan di bandingkan dengan tahun 2001 dan 2000 masingmasingnya adalah 3 hari dan 6 hari. Average collection period, menurut Munawir (1995:75) bertujuan untuk mengetahui waktu rata-rata pengumpulan piutang perusahaan yang diperoleh dengan cara membandingkan antar piutang rata-rata dengan jumlah penjualan x 360 hari. Semakin sedikit waktu yang diperlukan untuk mengumpulkan piutang, maka semakin baik bagi perusahaan. Dan juga menunjukkan baiknya kinerja karyawannya.

Perputaran piutang dari tahun 2000 ke tahun 2001 mengalami penurunan sebanyak 8,82 kali, sedangkan dari tahun 2001 ke tahun 2002 mengalami penurunan sebanyak 17,25 kali. Kalau ratio semakin rendah berarti ada over investmen dalam piutang sehingga memerlukan analisa lebih lanjut, mungkin karena bagian kredit dan penagihan bekerja 
tidak efektif atau mungkin ada perubahan dalam kebijaksanaan pemberian kredit.

Untuk tahun 2002 asset turn over Rumah Sakit Yos Sudarso adalah 1,67 kali. Dimana untuk Rp. 1 aktiva yang digunakan bisa menghasilkan Rp.1,67 pendapatan. Asset Turnover menurut Munawir (1995:98) bertujuan untuk mengetahui perputaran aktiva usaha untuk menghasilkan pendapatan bagi perusahaan dengan cara membandingkan antara penjualan bersih dengan aktiva usaha. Semakin tinggi perputaran aktiva usaha akan menghasilkan pendapatan yang semakin tinggi bagi perusahaan.

\section{PENUTUP}

\section{Kesimpulan}

Berdasarkan temuan dan pembahasan sebelumnya dimana pengukuran kinerja dilakukan dengan menggunakan sistem Balanced Scorecard Rumah Sakit Yos Sudarso Padang khususnya bagian IGD, maka dapat disimpulkan sebagai berikut:

Berdasarkan perspektif proses bisnis/intern, kinerja Bagian IGD sudah cukup baik. Bagian IG sudah melakukan perbaikan terus-menerus dalam proses penerimaan pasien, sedangkan berdasarkan perspektif keuangan, Return On Investment dari tahun ke tahun selalu meningkat, dari tahun 2000 ke 2001 meningkat sebesar 3\% dan dari tahun $2001 \mathrm{ke}$ tahun 2002 meningkat sebesar $1 \%$. Peningkatan ROI dari tahun ke tahun yang terlihat pada Tabel 2 di atas di pacu oleh 2 (dua) penyebab yaitu: peningkatan pertumbuhan pendapatan dan penurunan biaya. Return On Asset juga mengalami peningkatan, dari tahun 2000 ke tahun 2001 meningkat sebesar 1\% dan dari tahun $2001 \mathrm{ke}$ tahun 2002 meningkat sebesar $1 \%$.

\section{Saran}

a. Pada pihak manajemen Rumah Sakit Yos Sudarso Padang hendaknya dapat menyusun strateginya lebih baik lagi berdasarkan misi, visi dan tujuan rumah sakit, yang mana dari wawancara yang penulis dapatkan pihak rumah sakit dalam membuat strategi-strateginya tidak memilah-milah kepada empat persepektif, dan seharusnya strategi yang dibuat harus jelas misalnya pada perspektif keuangan strategi-strategi apa saja yang harus dilakukan oleh rumah sakit tersebut, begitu juga dengan 3 perspektif lainnya.

b. Pada perspektif keuangan tolok ukur yang digunakan oleh rumah sakit seharusnya tidak hanya menggunakan ROI, ROA dan ratio-ratio saja, tetapi sebagusnya rumah sakit dapat menggunakan tolok ukur-tolok ukur lain misalnya dengan menggunakan analisa EVA agar pengukuran yang dilakukan pada perspektif keuangan tersebut dapat lebih komprehensif lagi.

c. Pada pihak Rumah Sakit Yos Sudarso Padang disarankan untuk meningkatkan efisiensi dari pemakaian alat-alat medik, sehingga alat-alat medik tersebut dapat digunakan seefisien mungkin dan tidak menganggur dan dapat meningkatkan investasi pada aktiva tetap rumah sakit.

\section{DAFTAR PUSTAKA}

10.22202/economica.2012.v1.i1.112

Anthony, Robert N., dan Dearden, Jhon, (1992), Sistem Pegendalian Manajemen, Edisi Keenam, Binapura Aksara, Jakarta.

Irawan, Prasetya, (1999), Logika dan Prosedur Penelitian, Pengantar Teori dan Panduan Praktis Penelitian Sosial Bagi Mahasiswa dan Penelitian Pemula, STIALAN, Jakarta

Kaplan, Robert S., dan Norton, David P. (1992), The Balanced Scorecard Measures Tahat Drive Performance. Harvard Bussiness Review.

Moleong, Lexy J, (1994), Metodologi Penelitian Kualitatif, PT. Remaja Rosdakarya, Bandung.

Mulyadi dan Setyawan, Johny, (2001), Sistem Perencanaan dan Pengendalian Manajemen, Salemba Empat, Jakarta.

Mulyadi, (2001), Balanced Scorecard Alat Manajemen Kontemporer untuk Pelipatgandaan Kinerja Keuangan Perusahaan. Salemba Empat, Jakarta.

Munawir, S. Drs. 1995. “Analisa Laporan Keuangan". Yogyakarta. Liberty Yogyakarta. 
(1997), Akuntansi Manajemen, Universitas Gadja Mada, Edisi Keenam, Yogyakarta.

Nazir, Moh, (1999), Metode Penelitian, Ghalia Indonesia, Jakarta.

Tunggal, Widjaya, Amin, (2001), Pengukuran Kinerja dengan Balanced Scorecard, Harvarindo, Jakarta. 